\title{
КЛІНІЧНІ ВАРІАНТИ СОМАТОГЕННОГО АСТЕНІЧНОГО СИМПТОМОКОМПЛЕКСУ ТА КАРДІОВАСКУЛЯРНИЙ РИЗИК У КОМБАТАНТІВ
}

\section{Клінічні варіанти соматогенного астенічного симптомокомплексу та кардіоваскулярний ризик у комбатантів}

\section{Л. В. Черкашина ${ }^{1}$, І. І. Кириченко ${ }^{1,2}$, Г. П. Сябренко ${ }^{3,4}$}

Харківська медична академія післядипломної освіти МОЗ України ${ }^{1}$

Військово-медичний клінічний чентр Північного регіону Міністерства оборони України

КНП «Кіровоградський обласний клінічний госпіталь ветеранів війни» ${ }^{3}$

Донецький національний медичний університет моз України

Резюме. Актуальність дослідження визначається недосконалістю існуючих підходів до оцінки кардіоваскулярного ризику (KBP), що базуються на лабораторно-інструментальних дослідженнях, при яких не враховують ні психологічного портрету особистості, ні наявності непсихотичних розладів психічної сфрери. Саме це й вимагає удосконалити концепцію діяльності на первинному рівні надання допомоги задля підвищення ефрективності профрілактичних заходів та покращання прогнозу пацієнтів із високим КВР.

Мета дослідження - вивчити частоту та характер клінічних варіантів соматогенного астенічного симптомокомплексу серед комбатантів, стратифрікованих за рівнем КВР.

Матеріали і методи. Первинною інформаційною базою для виконання дослідження стали результати комплексного клініко-анамнестичного обстеження 450 пацієнтів комбатантів, серед яких 400 осіб мали НППС та які попередньо були стратиоріковані за рівнем кардіоваскулярного ризику (КВР), визначеним за методикою «SCORE». Застосування чієї методики передбачало урахування віку, статі, наявності тютюнокуріння, рівня артеріального тиску тощо і передбачало можливість екстраполяції можливого ризику на старший вік.

Результати. Серед 99 пацієнтів із мінімальним КВР виявлено, що САСК мало місце у $(21,2 \pm 4,1) \%$ обстежених: однаково поширеними були всі клінічні варіанти САСК (їх частота коливалась у межах від $(3,0 \pm 1,7) \%$ -
Clinical variants of somatogenic asthenic symptom complex and cardiovascular risk in combatants

L. V. Cherkashyna, I. I. Kyrychenko, G. P. Siabrenko Kharkiv Medical Academy of Postgraduate Education ${ }^{1}$ Military Medical Clinical Center of the Northern Region, Ministry of Defense of Ukraine ${ }^{2}$

Kirovograd Regional Clinical Hospital for War Veterans ${ }^{3}$ Donetsk National Medical University ${ }^{4}$

e-mail: serg_shklyar@ukr.net

Summary. The relevance of the study is determined by the imperfection of existing approaches in the assessment of cardiovascular risk (CVR), based on laboratory and instrumental assessments and does not take into account either the psychological portrait of the individual or the presence of non-psychotic mental disorders. This is what requires the improvement of the concept of activity at the primary level of care, in order to increase the effectiveness of preventive measures and improve the prognosis of patients with high CVR.

The aim of the study - to learn the frequency and nature of clinical variants of somatogenous asthenic symptom complex among combatants stratified by CVR level.

Materials and Methods. The primary information base for the study was the results of a comprehensive clinical and anamnestic examination of 450 combatants, including 400 people who had NSAIDs and who were previously stratified by the level of cardiovascular risk (CVR), determined by the method of "SCORE". The application of this technique took into account age, sex, the presence of smoking, blood pressure, etc. and provided for the possibility of extrapolating the possible risk to old age.

Results. Among 99 patients with minimal CVR, it was found that SASC occurred in (21.2 \pm 4.1$) \%$ of examined: equally common were all clinical variants of SASC (their frequency ranged from $(3.0 \pm 1.7) \%$ - asthenic, up to $(7.1 \pm 2.6) \%-$ astheno-anxiety and astheno-subdepressive). In this case, the intermediate position in terms of frequency was

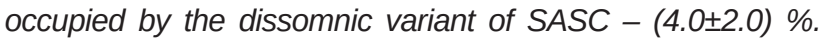
Among 102 patients with mean CVR, it was found that the 
астенічний, до $(7,1 \pm 2,6) \%$ - астено-тривожний та астено-субдепресивний). При цьому проміжне положення за показником частоти займав дисомнічний варіант CACK - $(4,0 \pm 2,0) \%$. Серед 102 пацієнтів з середнім КВР виявлено, що частота САСК у чій групі не відрізняється від аналогічного показника групи з мінімальнгим КВР та становила $(21,6 \pm 4,1) \%$, однак у структурі САСК групи з середнім КВР достовірна $(p \leq 0,05)$ більше клінічних варіантів астенічного типу, частота якого становила $(11,8 \pm 3,2) \%$, тоді як інші клінічні варіанти в цій групі діагностовані з однаковою частотою (у межах від $(2,0 \pm 1,4) \%$ - дисомнічний варіант до $(4,9 \pm 2,1) \%$ астено-субдепресивний, $p>0,05)$. Серед 97 пацієнтів із високим КВР виявлено, що САСК мав місце достовірно $(p \leq 0,05)$ рідше, ніж при мінімальному КВР - у $(10,1 \pm 3,2)$ $\%$ обстежених, а за частотою діагностування клінічні варіанти САСК виявлялися однаково часто (від $(1,0 \pm 1,0) \%$ - дисомнічний, до $(3,0 \pm 1,7) \%$ - астено-тривожний та астено-субдепресивний, $p>0,05)$.

Висновки. У дослідженні визначені частота та характер клінічних варіантів САСК у комбатантів із різним рівнем КВР та доведено наявність найбільш високої частоти астенічного типу $(p<0,05)$ в групі пацієнтів з середнім рівнем КВР порівняно з іншими клінічними варіантами. Астенічний тип САСК найбільш властивий хворим із реалізованим КВР та пацієнтам з середнім рівнем КВР, тоді як інші клінічні варіанти САСК виявлені з однаковою частотою серед пацієнтів з різним рівнем КВР.

Ключові слова: загальна практика - сімейна медицина; кардіоваскулярний ризик; комбатанти; реакції психічної дезадаптації.

\section{ВСТУП}

За даними Комітету Експертів ВООЗ та Європейських асоціацій кардіологів майже у 20,0 \% дорослого населення має підвищений артеріальний тиск, третина смертей від серцево-судинних захворювань (СС3) асоційована з десятьма основними фокторами ризику, з яких на високий рівень холестерину припадає 4,4 млн випадків, тютюнокуріння - 4,9 млн, артеріальну гіпертензію - 7,1 млн. Доведено, що при індексі маси тіла (IMT) у межax 25-28,9 кг/М² кардіоваскулярний ризик (КВР)

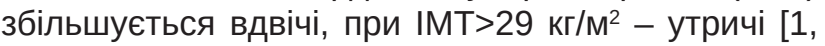
$4,14,16]$. На жаль, медико-психологічний контекст у оцінці кардіоваскулярного ризику практично відсутній. Дослідження, спрямовані на удосконалення первинної медико-санітарної допомоги (ПМСД) учасникам бойових дій (комбатантів) з індивідуалізацію ризикометричних підходів, $є$ актуальними $[6-9,13,16]$.

При визначені рівня КВР використовують як результати лабораторних досліджень, так і дихотомічні індикаторів ризику. Зокрема, згідно з існуючими уявленнями, шкала оцінки ризику «SCORE» призначена для прогнозування смертельного (коронарного чи некоронарного) захворювання в най- frequency of CVR in this group did not differ from the same

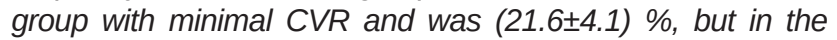
structure of CVR group with mean CVR is significant $(p \leq 0,05)$ more clinical variants of the asthenic type, the frequency of which was $(11.8 \pm 3.2) \%$, while other clinical variants in this group were diagnosed with the same frequency (in the range

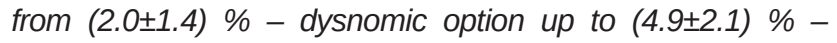
astheno-subdepressive, $p>0 . .05)$. Among 97 patients with high CVR, it was found that SASC occurred significantly $(p \leq 0.05)$ less often than with minimal CVR - in (10.1 \pm 3.2$) \%$ of examined, and the frequency of diagnosis of clinical variants of SASC were detected equally often (from (1.0 \pm 1.0$) \%-$ dyssomnic, to (3.0 \pm 1.7$) \%$ - astheno-anxiety and asthenosubdepressive, $p>0.05)$ Among 102 patients with realized CVR (patients with CVR) it was found that SASC occurred significantly $(p \leq 0.05)$ more often than at high levels of CVR - in (20.6 \pm 4.0$) \%$ of subjects: the most common was asthenic form of SASC $(p \leq 0.05)$, and the most rarely diagnosed - dissomnic variant of SASC - in $(2.0 \pm 1.4) \%$ of patients.

Conclusions. The study determined the frequency and nature of clinical variants of SASC in combatants with different levels of CVR and proved the presence of the highest frequency of asthenic type $(p<0.05)$ in the group of patients with moderate CVR compared to other clinical variants. It is proved that the asthenic type of SASC is most characteristic of patients with realized CVR and patients with an average

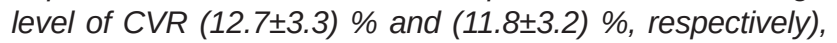
while other clinical variants of SASC were detected with the same frequency among patients with different levels of CVR.

Key words: general practice - family medicine; cardiovascular risk; combatants; reactions of mental maladaptation.

ближчі 10 років. Тоді як в молодому віці технологія оцінки КВР носить проспективний характер. І, недивлячись на меншу точність, ніж у старших вікових групах, технологія дозволяє на рівні первинної ланки надання медичної допомоги індивідуалізувати засоби цільової профрілактики кардіоваскулярних подій [6-10]. Недоліком існуючих підходів $€$ лабораторно-інструментальна фрормалізація в оцінках КВР, яка не враховує ні психологічний портрет особистості, ні наявність непсихотичних розладів психічної сорери. Це й вимагає удосконалення концепції діяльності на первинному рівні надання допомоги задля підвищення ефективності профрілактичних заходів та покращення прогнозу пацієнтів із високим КBP $[11,13,14]$.

Метою дослідження було вичити частоту та характер клінічних варіантів соматогенного астенічного симптомокомплексу серед комбатантів, стратиорікованих за рівнем КВР.

\section{МАТЕРІАЛИ I МЕТОДИ}

Первинною інформаційною базою для виконання дослідження стали результати комплексного клініко-анамнестичного обстеження 450 
пацієнтів-комбатантів, серед яких 400 осіб мали НППС та які попередньо були стратифіковані за рівнем кардіоваскулярного ризику (КВР), визначеним за методикою «SCORE» $[1,16]$. Застосування цієї методики передбачало урахування віку, статі, наявності тютюнокуріння, рівня артеріального тиску та інших і передбачало можливість екстраполяції можливого ризику на старший вік $[1,4]$. До групи мінімального (низького) КВР віднесено 99 пацієнтів ( $\left.\mathrm{n}_{\mathrm{MP}}=99\right)$, середнього - 102 пацієнти $\left(\mathrm{n}_{\mathrm{CP}}=102\right)$, високого КВР - 97 пацієнтів $\left(\mathrm{n}_{\mathrm{BP}}=97\right)$ та до групи з реалізованим КВР віднесего 102 особи $\left(\mathrm{n}_{\mathrm{x}}=104\right)$ з діагностованими серцево-судинними захворюваннями, відповідно до загальноприйнятих клінічних протоколів [13]. Групи не відрізнялись поділом за віком та статтю. Дослідження виконано за стандартизованою програмою збирання, накопичення та аналізу результатів. При виконанні дослідження застосовано відомі та широко вживані клініко-статистичні та клініко-інформаційні методи: анамнестичний кількісний аналіз [2, 3, 12], варіаційну статистику [12], імовірнісний розподіл клінічних ознак з оцінкою достовірності одержаних результатів [12].

\section{РЕЗУЛЬТАТИ Й ОБГОВОРЕННЯ}

Клініко-психопатологічне дослідження дозволило визначити структуру САСК і загальні закономірності розподілу його клінічних варіантів залежно від рівня КВР.

Разом з тим, ми виявили і певні відмінності, тобто кожна ризикометрична група мала свої кількісні та якісні особливості клінічної структури САСК. Результати дослідження частоти різних форм САСК у ризикометричних групах та в групі хворих із маніфестованою КВП представлено в таблиці. Так, серед 99 пацієнтів із мінімальним КВР виявлено, що
САСК мали місце у $(21,2 \pm 4,1) \%$ обстежених: однаково поширеними були всі клінічні варіанти САСК (ïх частота коливалась у межах від $(3,0 \pm 1,7) \%$ - астенічний, до $(7,1 \pm 2,6) \%$ - астено-тривожний та астено-субдепресивний). При цьому проміжне положення за показником частоти займав дисомнічний варіант САСК - $(4,0 \pm 2,0) \%$ (рис.).

Серед 102 пацієнтів із середнім КВР виявлено, що частота САСК у цій групі не відрізняється від аналогічного показника групи з мінімальнгим КВР та становила $(21,6 \pm 4,1) \%$, однак у структурі САСК групи з середнім КВР достовірно $(p \leq 0,05)$ більше клінічних варіантів астенічного типу, частота якого становила $(11,8 \pm 3,2) \%$, тоді як інші клінічні варіанти в цій групі діагностовані з однаковою частотою (у межах від $(2,0 \pm 1,4) \%$ - дисомнічний варіант до $(4,9 \pm 2,1) \%$ - астено-субдепресивний, р>0,05).

Серед 97 пацієнтів 3 високим КВР виявлено, що САСК мав місце достовірно $(p \leq 0,05)$ рідше, ніж при мінімальному КВР, - у $(10,1 \pm 3,2)$ \% обстежених, а за частотою діагностування клінічні варіанти САСК виявлялися однаково часто (від $(1,0 \pm 1,0) \%$ - дисомнічний, до $(3,0 \pm 1,7) \%$ - астено-тривожний та астено-субдепресивний, $р>0,05)$.

Серед 102 пацієнтів із реалізованим КВР (хворі на СС3) виявлено, що САСК мали місце достовірно $(p \leq 0,05)$ частіше, ніж при високому рівні КВР у $(20,6 \pm 4,0)$ \% обстежених: найбільш поширеною була астенічна фрорма САСК (p $\leq 0,05)$, а найбільш рідко діагностованим - дисомнічний варіант САСК - у $(2,0 \pm 1,4) \%$ хворих.

Таким чином, астеничний тип САСК найбільш властивий хворим з реалізованим КВР та пацієнтам 3 середнім КВР (відповідно $(12,7 \pm 3,3) \%$ та $(11,8 \pm 3,2) \%$, р>0,05), тоді як інші клінічні варіанти САСК виявлені з однаковою частотою серед пацієнтів з різним рівнем КВР.

Таблиця. Частота клінічних варіантів соматогенного астенічного симптомокомплексу залежно від рівня кардіоваскулярного ризику

\begin{tabular}{|c|c|c|c|c|c|}
\hline \multirow{2}{*}{\multicolumn{2}{|c|}{$\begin{array}{l}\text { Клінічний варіант соматогенного } \\
\text { астенічного симптомокомплексу }\end{array}$}} & \multicolumn{4}{|c|}{ Рівень кардіоваскулярного ризику } \\
\hline & & \multirow{2}{*}{$\begin{array}{c}\begin{array}{c}\text { мінімальний } \\
\left(\mathrm{n}_{\mathrm{MP}}=99\right)\end{array} \\
3\end{array}$} & \multirow{2}{*}{$\begin{array}{c}\begin{array}{c}\text { середній } \\
\left(\mathrm{n}_{\mathrm{CP}}=102\right)\end{array} \\
12\end{array}$} & \multirow{2}{*}{$\begin{array}{c}\begin{array}{c}\text { високий } \\
\left(\mathrm{n}_{\mathrm{BP}}=97\right)\end{array} \\
2\end{array}$} & \multirow{2}{*}{$\begin{array}{c}\begin{array}{c}\text { xворі на СC3 } \\
\left(n_{x}=102\right)\end{array} \\
13\end{array}$} \\
\hline Астенічний & абс., осіб & & & & \\
\hline & $P \pm m, \%$ & $3,0 \pm 1,7^{6}$ & $11,8 \pm 3,2^{a, c}$ & $2,0 \pm 1,4^{6}$ & $12,7 \pm 3,3^{\mathrm{a}, \mathrm{c}}$ \\
\hline \multirow[t]{2}{*}{ Астено-субдепресивний } & абс., осіб & 7 & 5 & 3 & 3 \\
\hline & $\mathrm{P} \pm \mathrm{m}, \%$ & $7,1 \pm 2,6$ & $4,9 \pm 2,1$ & $3,0 \pm 1,7$ & $2,9 \pm 1,7$ \\
\hline \multirow[t]{2}{*}{ Астено-тривожний } & абс., осіб & 7 & 3 & 3 & 3 \\
\hline & $\mathrm{P} \pm \mathrm{m}, \%$ & $7,1 \pm 2,6$ & $2,9 \pm 1,7$ & $3,0 \pm 1,7$ & $2,9 \pm 1,7$ \\
\hline \multirow[t]{2}{*}{ Дисомнічний } & абс., осіб & 4 & 2 & 1 & 2 \\
\hline & $\mathrm{P} \pm \mathrm{m}, \%$ & $4,0 \pm 2,0$ & $2,0 \pm 1,4$ & $1,0 \pm 1,0$ & $2,0 \pm 1,4$ \\
\hline \multirow[t]{2}{*}{ Усього } & абс., осіб & 21 & 22 & 9 & 21 \\
\hline & $\mathrm{P} \pm \mathrm{m}, \%$ & $21,2 \pm 4,1^{c}$ & $21,6 \pm 4,1^{\mathrm{c}}$ & $10,1 \pm 3,2^{\mathrm{a}, \mathrm{b}}$ & $20,6 \pm 4,0^{c}$ \\
\hline
\end{tabular}

Примітки: 1) а - достовірна відмінність порівняно з групою мінімального КВР, при p $\leq 0,05$;

2) ${ }^{6}$ - достовірна відмінність порівняно з групою середнього рівня $\mathrm{KBP}$, при $\mathrm{p} \leq 0,05$;

3) ${ }^{c}$ - достовірна відмінність порівняно з групою високого КВР, при $\mathrm{p} \leq 0,05$. 


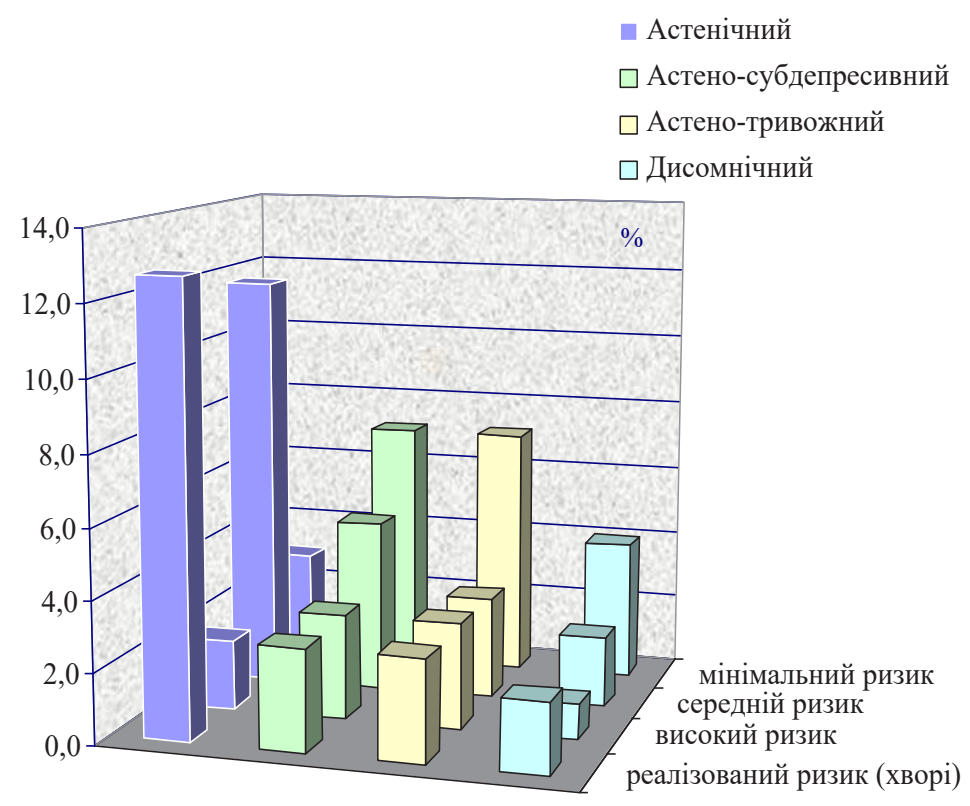

Рис. Частота (у \%) та характер соматогенного астенічного симптомокомплексу залежно від рівня кардіоваскулярного ризику.

Отже, частота САСК у різних ризикометричних групах пацієнтів коливалась у межах від $(10,1 \pm 3,2)$ $\%$ до $(21,6 \pm 4,1) \%$ та достовірно $(p \leq 0,05)$ була вищою серед пацієнтів із реалізованим КВР, ніж в групі з високим КВР. При цьому виявлені достовірні відмінності у частоті САСК залежно від рівня КВР, що може бути використано в системі індивідуалізації психокорекційного впливу. Наведене свідчить на користь розробки дисеренційованих заходів у системі медико-психологічного моніторингу осіб із різним рівнем КВР та індивідуалізованого клінікопсихологічного супроводу не тільки хворих на СС3, але й осіб, насамперед з високим рівнем КВР.

Напрямки подальших досліджень пов'язані 3 вивченням закономіроностей формування синдромологічної структури інших НППС серед комбатантів різних ризикометричних груп КВР.

\section{СПИСОК ЛІТЕРАТРУРИ}

1. Горбась I. М. Шкала SCORE у клінічній практиці: переваги й обмеження / I. М. Горбась // Здоров'я України. - 2008. - № 11(1). - С. 40-41.

2. Личко А. Е. Медико-психологическое обследование соматических больных / А. У. Личко, Н. Я. Иванов // Журн. невропатологии и психиатрии им. С. С. Корсакова. - 1980. - Т. 80, № 8. - С. 1195-1198.

3. Лищук В. А. Инфрорматизация клинической медицине / В. А. Лищук // Клин. информатика и телемедицина. -2004 . - № 1. - С. 7-13.

4. Нетяженко В. 3. Пацієнт високого кардіоваскулярного ризику: як покращити прогноз / В. 3. Нетяженко, О. Г. Пузанова // Внутрішня медицина. - 2008. - № 5-6. - С. $123-129$.

5. Органов Р. Г. Новый способ оценки индивидуального сердечно-сосудистого суммарного риска для

\section{ВИСНОВКИ}

1. Визначені частота та характер клінічних варіантів САСК у пацієнтів із різним рівнем КВР та доведено наявність найбільш високої частоти астенічного типу $(p<0,05)$ в групі пацієнтів із середнім рівнем КВP порівняно з іншими клінічними варіантами.

2. Доведено, що астенічний тип САСК є найбільше властивий хворим із реалізованим КВР та пацієнтам із середнім рівнем КВР (відповідно $(12,7 \pm 3,3) \%$ та $(11,8 \pm 3,2) \%)$, тоді як інші клінічні варіанти САСК виявлені з однаковою частотою серед пацієнтів із різним рівнем КВР.

3. Частота та характер САСК, насамперед у пацієнтів із високим КВР, визначають потребу в більш детальному вивченні 3 позицій ефективного використання засобів освітньо-поведінкової корекції як компоненту медико-психологічного супроводу пацієнтів із КВР на рівні ПМСД.

населения России / Р. Г. Органов, С. А. Шальнова, А. М. Калинина // Кардиология. - 2008. - № 5. C. 85-89.

6. Панченко М. С. Медико-психологічні, санологічні та генеалогічні передумови фрормування підвищеного серцево-судинного ризику у пацієнтів з хронічними захворюваннями шлунково-кишкового тракту / М. С. Панченко // Проблеми екологічної та медичної генетики і клінічної імунології : збірник наукових праць. - 2013. Вип. 4. (118). - С. 280-287.

7. Панченко М. С. Прогностичне значення медикопсихологічних фракторів в оцінці серцево-судинного ризику / М. С. Панченко // Вісник проблем медицини та біології. - 2013. - Вип. 4, Т. 1. - С. 193-197.

8. Панченко М. С. Психологічні особливості хворих з соматичною патологією та кардіоваскулярний ризик / 
М. С. Панченко // Вісник проблем медицини та біології. 2013. - Вип. 4, Т. 2. - С.149-153.

9. Санологія та клінічна медицина: методологія та досвід популяційного аналізу психосоматичних розладів у молодому віці / М. С. Панченко, С. П. Шкляр, Д. П. Перцев, Л. В. Черкашина // Проблеми екологічної та медичної генетики і клінічної імунології : збірник наукових праць. - 2011. - Вип. 6. (108). - С. 457-467.

10. Приходько В. Ю. Пациент высокого риска - кто он ? / В. Ю. Приходько // Здоров'я України. - 2010. № 3. - C.18-19.

11. Сіренко Ю. М. Ефективність профрілактичних заходів для попередження розвитку серцево-судинних захворювань / Ю. М. Сіренко // Сімейна медицина. - 2006. - № 1. - C. 52-60.

12. Соціальна медицина та організація охорони здоров'я : підручник / заг. ред. В. М. Москаленко, Ю. В. Вороненко. - Тернопіль, 2002. - С. 50-75.

13. Соціометрична оцінка якості медичної допомоги в амбулаторіях загальної практики-сімейної медицини :

\section{REFERENCES}

1. Horbas IM. [SCORE scale in clinical practice: advantages and limitations]. Zdorovia Ukrainy. 2008;11(1): 40-1. Ukrainian.

2. Lichko AYe, Ivanov NYa. [Medical and psychological examination of somatic patients] Zhurnal nevropatologii i psikhiatrii im. S.S.Korsakova. 1980;80(8): 1195-8. Russian.

3. Lishchuk, VA. [Informatization of clinical medicine]. Klinicheskaya informatika i telemeditsina. 2004;1: 7-13. Russian.

4. Netyazhenko VZ, Puzanova OH. [Patient with high cardiovascular risk: how to improve the prognosis]. Vnutrishnia medytsyna. 2008;5-6: 123-9. Ukrainian.

5. Organov RG, Shalynova SA, Kalinina AM. [A new way of assessing the individual cardiovascular total risk for the population of Russia]. Kardiologiya. 2008;5: 85-9. Russian.

6. Panchenko MS. [Medico-psychological, sanological and genealogical prerequisites for the formation of increased cardiovascular risk in patients with chronic diseases of the gastrointestinal tract]. Problemy ekolohichnoi ta medychnoi henetyky i klinichnoi imunolohii: Zbirnyk naukovykh prats. 2013;4(118): 280-7. Ukrainian.

7. Panchenko MS. [Prognostic value of medical and psychological factors in the assessment of cardiovascular risk]. Visnyk problem medytsyny ta biolohii. 2013;4(1): 1937. Ukrainian.

8. Panchenko MS. [Psychological features of patients with somatic pathology and cardiovascular risk]. Visnyk problem medytsyny ta biolohii. 2013;4(2): 149-53. Ukrainian.

9. Panchenko MS, Shklyar SP, Pertsev DP, Cherkashyna LV. [Sanology and clinical medicine: methodology and experience of population analysis of psychosomatic disor- метод. рекомен. МОЗ України ; укладачі: С. П. Шкляр, І. М. Кравченко, Л. В. Черкашина, О. І. Сердюк, М. С. Панченко. - К., 2013. - 20 с.

14. Шальнова С. А. Оценка суммарного риска сердечно-сосудистых заболеваний. Комментарии к европейским рекомендациям по просрилактике сердечнососудистых заболеваний / С. А. Шальнова, О. В. Вихирева // Рациональная фрармакотерапия. - 2005. - № 3. - C. $54-56$

15. Санологія та клінічна медицина: методичні аспекти вивчення фракторів ризику психосоматичних розладів / С. П. Шкляр, М. С. Панченко, Д. П. Перцев, Л.В.Черкашина // Проблеми екологічної та медичної генетики і клінічної імунології : зб. наукових праць. - 2011. -Вип. 6 (108). - С. 495-505.

16. Bhatt D. L. International prevalence, recognition, and treatment of cardiovascular risk factors in outpatients with atherothrombosis / D. L. Bhatt, P. G. Steg, E. M. Ohman // JAMA. - 2006. - No. 295. - P.180-189.

ders at a young age]. Problemy ekolohichnoyi ta medychnoi henetyky i klinichnoi imunolohii: Zbirnyk naukovykh prats. 2011;6(108): 457-67. Ukrainian.

10. Prikhodko VYu. [High risk patient - who is he?]. Zdorovia Ukrainy. 2010;3: 18-19. Ukrainian.

11. Sirenko YuM. [Effectiveness of preventive measures to prevent the development of cardiovascular diseases]. Simeina medytsyna. 2006;1: 52-60. Ukrainian.

12. Moskalenko VM, Voronenko YV. Eds. Social medicine and health care organization: Textbook [Соціальна медицина та організація охорони здоров'я: підручник] Ternopil; 2002. Ukrainian.

13. Shklyar SP, Kravchenko IM, Cherkashyna LV, Serdyuk OI, Panchenko MS. [Sociometric assessment of the quality of medical care in outpatient clinics of general practice-family medicine]. Methodical recommendations of the Ministry of Health of Ukraine. Kyiv; 2013. Ukrainian.

14. Shalnova SA, Vikhireva OV. [Assessment of the total risk of cardiovascular disease. Comments on the European guidelines for the prevention of cardiovascular diseases]. Ratsionalnaya farmakoterapiya. 2005;3: 54-6. Russian.

15. Shklyar SP, Panchenko MS, Pertsev DP, Cherkashyna LV. [Sanology and clinical medicine: methodological aspects of studying risk factors for psychosomatic disorders]. Problemy ekolohichnoi ta medychnoi henetyky i klinichnoi imunolohii: Zbirnyk naukovykh prats. 2011;6(108): 495-505. Ukrainian.

16. Bhatt DL, Steg PG, Ohman EM. International prevalence, recognition, and treatment of cardiovascular risk factors in outpatients with atherothrombosis. JAMA. 2006;295: 180-9. 